\title{
EFEKTIFITAS KOMUNIKASI ANTARPRIBADI GURU DENGAN SISWA \\ DALAM PROSES BELAJAR MENGAJAR \\ (Studi Kasus pada Siswa Tunarungu di Sekolah Luar Biasa Sumber Budi \\ Petukangan Selatan, Jakarta Selatan)
}

\author{
Linda Islami dan Armaini Lubis \\ Fakultas Ilmu Komunikasi, Universitas Budi Luhur \\ Linda.islami@budiluhur.ac.id \\ Armaini.lubis@budiluhur.ac.id
}

\begin{abstract}
Teachers' interpersonal communication with deaf students is very effective in implementing the learning process. Unfortunately, not all students have good skills in communication, especially for those who cannot hear normally. The research use the theory of self attitude and social infiltration theory. The research use qualitative methods with Post-positivism paradigm. The results of the study, there are obstacles in learning process, because deaf students are normally poor acquiring language, they can have limited understanding of what teacher explain through gestures, body movements and lips. Effective communication occurs between teachers and students, heart to heart conversation formed transparency between them. Students' openess make teachers feel empathy towards what students feel. Teachers constantly pay attention and affection toward students. Openness can make teachers treat students full of patient. The learning method is a demonstration, question and answer, lectures, assignments, and the methods of drill or repetition. It makes interpersonal communication between teachers and deaf students become more effective. Suggestions, materials delivery method outside mathematics lessons should use the pictures, so students do not need to imagine, because the imagination of deaf students is very low.
\end{abstract}

\section{Keywords: Effectiveness, interpersonal communication, learn, teach}

\begin{abstract}
Abstrak
Komunikasi antarpribadi guru dengan siswa tunarungu merupakan hal yang sangat efektif dalam melaksanakan proses belajar mengajar. Sayangnya tidak semua siswa mempunyai kemampuan yang baik dalam berkomunikasi, Salah satunya adalah penderita tunarungu, yaitu siswa yang tidak bisa mendengar secara maksimal. Teori yang digunakan adalah Teori penyikapan diri dan Teori penyusupan sosial. Metode penelitian menggunakan metode kualitatif. Paradigma penelitian adalah Post-positivisme. Hasil penelitian, Terdapat hambatan dalam proses belajar mengajar, karena siswa tunarungu sangat miskin dengan bahasa, Siswa memahami apa yang guru jelaskan melalui mimik bibir dan gerakan tubuh.
\end{abstract}


Terjadi komunikasi efektif antara guru dengan siswa, karena adanya percakapan dari hati ke hati maka terbentuklah keterbukaan siswa tunarungu kepada gurunya. Keterbukaan siswa membuat guru empati dan merasakan apa yang dirasakan oleh siswa. Guru terus menerus memberikan perhatian, kasih sayang. Adanya keterbukaan, membuat guru memperlakukan siswanya penuh kesabaran. Metode belajar adalah demonstrasi, tanya jawab, ceramah, penugasan, dan metode drill atau pengulangan kata. Hal ini menjadikan komunikasi antarpribadi guru dan siswa tunarungu menjadi lebih efektif. Saran, Metode penyampaian materi di luar pelajaran matematika sebaiknya dengan menggunakan gambar, jadi siswa tidak perlu membayangkan, karena imajinasi siswa tunarungu sangat rendah.

Kata kunci : Efektifitas, komunikasi antarpribadi, belajar, mengajar

\section{PENDAHULUAN}

Sekolah merupakan tempat untuk menimba pengetahuan yang merupakan hal terpenting dalam merubah kehidupan siswa, ini berarti bahwa setiap siswa berhak mendapatkan dan berharap untuk selalu berkembang dalam dunia pendidikan. Pendidikan secara umum mempunyai arti suatu proses kehidupan dalam mengembangkan diri setiap siswa untuk dapat hidup dan melangsungkan kehidupan yang lebih baik di masa depan. Sehingga menjadi siswa yang terdidik. Pendidikan kita dapatkan melalui lingkungan keluarga, lingkungan masyarakat dan lingkungan sekolah.

Siswa yang disayangi oleh keluarga cenderung untuk menyayangi keluarganya kembali, sehingga siswa akan merasa dibutuhkan dalam keluarganya. Oleh sebab itu keluarga sebagai sumber kekuatan yang membangun perkembangan siswa. Hal ini akan timbul suatu situasi yang saling butuh membutuhkan, saling menghargai, saling menyayangi dan pada akhirnya saling mendukung perkembangan siswa.

Di dalam keluarga yang memberi kesempatan maksimum dalam dunia pendidikan adalah orang tua. Dalam lingkungan keluarga harga diri berkembang karena dihargai, diterima, dicintai, dan dihormati sebagai manusia. Itulah pentingnya mengapa kita menjadi orang yang terdidik di lingkungan keluarga. 
Orang tua berkewajiban untuk memberikan kesempatan dalam dunia pendidikan dan pendidikan yang pertama adalah lingkungan keluarga.

Sedangkan di lingkungan sekolah yang menjadi pendidik adalah guru. Alangkah pentingnya pendidikan itu. Guru sebagai pendidik memberikan ilmunya sesuai dengan kemampuan yang ia miliki.

Peran guru sebagai pendidik merupakan peran memberi bantuan dan dorongan, serta tugas-tugas yang berkaitan dengan mendisiplinkan siswa agar siswa dapat mempunyai rasa tanggung jawab dengan apa yang dia lakukan. Guru juga harus berupaya agar pelajaran yang diberikan dapat dipahami oleh siswa dalam proses belajar mengajar.

Selain itu peranan lingkungan masyarakat juga penting bagi perkembangan siswa. Hal ini berarti memberikan gambaran tentang bagaimana kita hidup bermasyarakat. Demikian bila kita berinteraksi dengan masyarakat maka mereka akan menilai kita, bahwa tahu mana orang yang terdidik, dan yang tidak terdidik.

Seluruh warga negara berhak memperoleh pendidikan yang layak sesuai dengan yang diamanatkan dalam undang-undang dasar 1945 Republik Indonesia Pasal 31 yang berisi (1) Tiap-tiap warga negara berhak mendapat pengajaran. (2) Pemerintah mengusahakan dan menyelenggarakan satu sistem pengajaran nasional, yang diatur dengan undang-undang.

Pendidikan yang layak dan bermutu merupakan sesuatu yang sangat penting dalam kehidupan menjadi lebih baik dimasa depan. Melalui proses pendidikan itulah kepribadian anak dimatangkan dan dikembangkan, sehingga seorang siswa menjadi anak yang dewasa, utuh, dan mandiri. Proses pendidikan sangat diperlukan bagi siswa, termasuk bagi siswa yang berkesulitan untuk menerima materi pelajaran atau memiliki kekurangan seperti anak tuna rungu.

Kesulitan menerima materi di karenakan terdapatnya suatu kekurangan dalam diri siswa, sehingga informasi yang disampaikan oleh Guru pun tidak akan diterima secara maksimal. Keberhasilan proses belajar mengajar ada hubungannya dengan cara guru dalam menyampaikan materi pelajaran kepada siswa. Oleh karena itu penyampaian materi ada hubungannya dengan proses komunikasi yang baik antara siswa dengan guru. 
Selain itu, siswa yang mempunyai kelainan akan mengalami kesulitan dalam melakukan komunikasi di lingkungan sekolah, baik di sekolah atau di luar sekolah. Di dalam dunia pendidikan komunikasi sangat diperlukan untuk kelangsungan proses belajar mengajar. Adanya komunikasi yang baik, maka proses belajar mengajar pun akan tersampaikan dengan baik juga.

Menurut Richard West dan Turner (2008:32) "Komunikasi adalah proses sosial dimana individu-individu menggunakan simbol-simbol untuk menciptakan dan menginterpretasikan makna dalam lingkungan mereka”. Jadi komunikasi sangat dibutuhkan oleh makhluk sosial yang membutuhkan manusia lain untuk mempertahankan kelangsungan hidupnya, memupuk hubungan dan memperoleh kebahagiaan.

Komunikasi tidak dapat dipisahkan dari kehidupan dan perkembangan siswa, sejak pertama anak dilahirkan sudah melakukan kegiatan komunikasi. Hubungan antar manusia tercipta melalui komunikasi, baik komunikasi secara verbal (lisan dan tulisan) maupun non verbal (symbol, gambar, atau media komunikasi lainnya).

Lingkungan sekolah, pada umumnya komunikasi yang digunakan adalah komunikasi antarpribadi yang biasa dilakukan untuk proses belajar mengajar dan interaksi sehari-hari di lingkungan sekolah. "Komunikasi antarpribadi adalah komunikasi yang terjadi secara langsung antara dua orang” Richard West dan Turner (2008:34).

Berdasarkan uraian masalah di atas, peneliti membatasi atau ruang lingkup penelitian adalah efektifitas komunikasi antarpribadi guru dengan siswa dalam proses belajar mengajar. (Studi Kasus pada Siswa Tunarungu di Sekolah Luar Biasa Sumber Budi Petukangan Selatan, Jakarta Selatan)

Tujuan penelitian adalah untuk mengetahui efektifitas komunikasi antarpribadi guru dengan siswa dalam proses belajar mengajar. (Studi Kasus pada Siswa Tunarungu di Sekolah Luar Biasa Sumber Budi Petukangan Selatan, Jakarta Selatan). Teori yang digunakan adalah Teori penyikapan diri, Teori penyusupan sosial. Teori Interaksi Imajiner. 


\section{KERANGKA PEMIKIRAN}

\section{Teori Penyikapan Diri}

Menurut Devito (2008:36) "Penyikapan diri adalah membeberkan informasi tentang diri sendiri dengan sengaja”. Penyikapan diri merupakan suatu usaha untuk membiarkan keaslian memasuki hubungan sosial kita. Kita membiarkan bahkan mengusahakan orang lain mengetahui keadaan kita apa adanya. Berbagai penelitian menunjukan, kemampuan kita mengungkapkan diri kita apa adanya paling tidak dengan satu orang, membuat kepribadian kita baik.

\section{Teori Penyusupan Sosial}

Teori ini merupakan hasil pemikiran Irwin Altman dan Dalmas Taylor (dalam Littlejohn dan Foss, 2009:48). Altman dan Taylor mengumpamakan struktur kepribadian seseorang dengan struktur anak bawang merah yang berlapislapis.

a. Lapisan terluar dari kepribadian seseorang adalah bagian dari diri seseorang yang tampak dari luar. Misalnya: Adi seorang siswa selalu berpakaian rapi.

b. Apabila kita dapat menembus lapisan luar ini, seseorang akan dapat mengetahui bagian yang merupakan wilayah semi-private dari orang tersebut yaitu berupa tingkah laku tertentu yang hanya diketahui oleh oleh orang-orang tertentu. Misalnya: Adi menghargai kebebasan, memiliki keyakinan agama yang kuat, memiliki prejudice terhadap komunitas tertentu.

c. Apabila kemudian kita dapat menembus lapisan ini hingga bagian terdalam maka kita akan mengetahui wilayah pribadi unik dari seseorang. Misalnya: konsep diri, nilai-nilai hidup, perasaan-perasaan yang mendalam tentang orang tertentu, masalah-masalah yang belum terselesaikan dalam hidupnya.

Teori ini terdapat kedalaman penyusupan yang berkaitan dengan derajat keintiman.

Menurut Altman dan Dalmas Taylor (dalam Littlejohn dan Foss, 2009:38) Ada empat hal yang berkaitan dengan proses untuk menuju kedalaman, yaitu:

a. Informasi yang bersifat lebih sering dipertukarkan dan bersifat segera di banding informasi yang lebih rahasia.

b. Keterbukaan diri merupakan hal-hal yang bersifat "saling", terutama pada tahap awal perkembangan dengan cepat pada awal perkembangan hubungan. 
c. Penyusupan sosial berkembang dengan segera ketika mencapai bagian terdalam dari lapisan kepribadian orang-orang yang terlibat.

d. Penyusupan ulang merupakan proses bertahap pada lapisan demi lapisan kepribadian kita.

\section{Teori Interaksi Imajiner}

Gambaran-gambaran mental mengenai komunikasi antarpribadi

Teori ini ditulis oleh James M. Honeycutt (2008) sebagai salah satu teori komunikasi antarpribadi yang terpusat pada individu. Adalah biasa dalam kehidupan sehari-hari mengharapkan pertemuan-pertemuan dengan orang-orang yang kita kenal dan akan berinteraksi dengan mereka.

Teori Interaksi Imjiner didasarkan dalam karya para ahli interaksionisme simbolik dan naskah para ahli teori kognitif termasuk Mead (1934), Dewey (1922), Schultz, dan Abelson (1976). Mead membahas percakapan yang diinternalisasikan atau dihayati mengenai gerak isyarat dimana para pelaku individual yang secara sadar memonitor tindakan sosial dengan meninjau bagian akhir alternatif mengenai setiap tindakan tertentu dimana mereka terlibat. Individu-individu menggunakan dialog-dialog internal dalam pikiran-pikiran mereka untuk menguji bermacam-macam skenario yang mungkin mengenai sebuah peristiwa di muka dari suatu tindakan. Interaksi imajiner digunakan secara strategis sebagai pengganti percakapan imajiner atau dialog internal, karena interaksi imajiner merupakan istilah yang lebih luas termasuk pula imajiner verbal dan nonverbal. Imajiner visual mencerminkan suasana interaksi. (dalam, Budyatna, 2015:740

\section{METODE PENELITIAN}

Langkah-langkah yang dilakukan dalam penelitian ini adalah 1. Pembatasan masalah, masalah yang diteliti adalah efektifitas komunikasi antarpribadi guru dengan siswa dalam proses belajar mengajar. (Studi Kasus pada Siswa Tunarungu di Sekolah Luar Biasa Sumber Budi Petukangan Selatan, Jakarta Selatan). Tema yang diangkat dalam penelitian ini adalah bagaimana proses belajar mengajar antara guru dengan siswa tunarungu. 3. Pengumpulan data dengan menggunakan wawancara pada guru dan pengamatan lapangan. 4. Interpretasi terhadap maknamakna yang terdapat dalam kasus. Hal ini dapat dilihat pada hasil penelitian dan pembahasan. 
Pendekatan penelitian yang digunakan adalah pendekatan kualitatif. Karena peneliti ingin memahami proses belajar mengajar Siswa Tunarungu di Sekolah Luar Biasa Sumber Budi Petukangan Selatan, Jakarta Selatan.

Menurut Richie, Penelitian kualitatif adalah upaya untuk menyajikan dunia sosial perspektifnya di dalam dunia, dari segi konsep, prilaku persepsi dan persoalan tentang manusia yang diteliti. (dalam, Moleong, 2010:6)

Metode penelitian yang digunakan adalah studi kasus, Studi kasus adalah penelitian yang bertujuan untuk mempelajari secara intensif mengenai unit sosial tertentu, yang meliputi individu, kelompok, lembaga dan masyarakat (depdikbud, 1982/1983:11). (dalam, Rianto, 1996:20)

Menurut K. Yin (2008) Secara umum, studi kasus merupakan strategi yang lebih cocok bila pokok pertanyaan suatu penelitian berkenaan dengan "how: atau "why". Bila penelitian hanya memiliki sedikit peluang untuk mengontrol peristiwa-peristiwa yang akan diselidiki dan bilamana fokus penelitiannya terletak pada fenomena kontemporer (masa kini) di dalam konteks kehidupan nyata. (dalam, kriyantoro 2010:1)

Ada empat tipe desain penelitian studi kasus sebagai berikut :

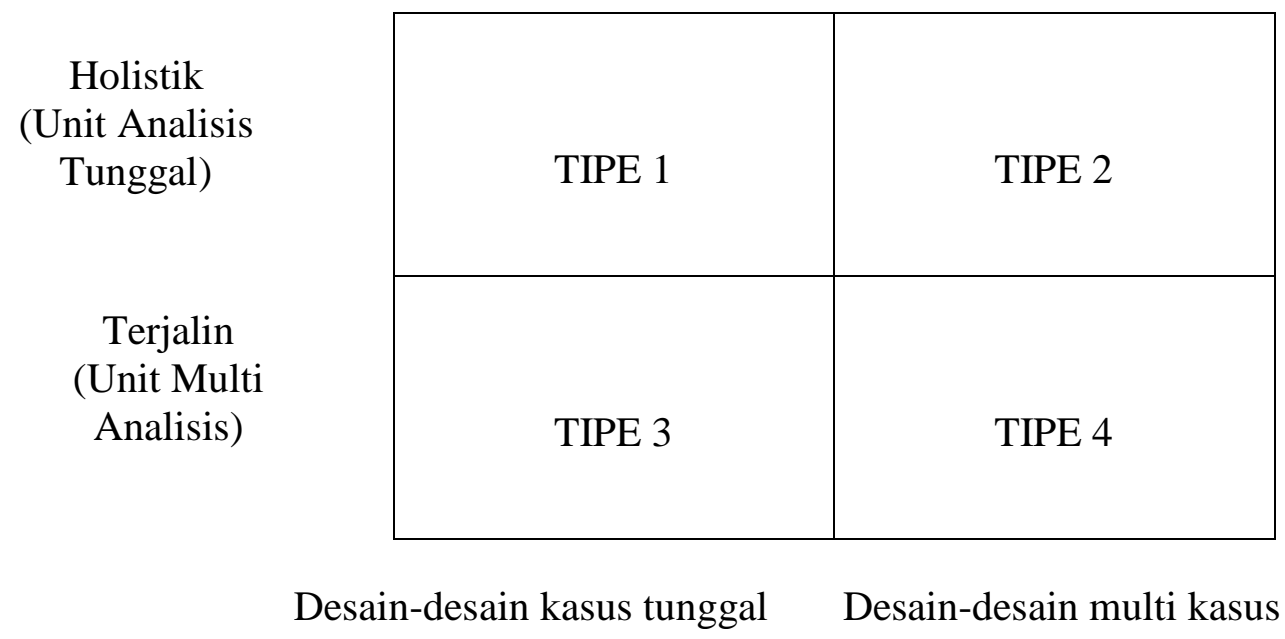

\section{Gambar 3.1}

\section{Tipe-tipe Dasar Desain Studi Kasus}

Menurut K. Yin mengenai penjelasan empat tipe desain penelitian pada bagan di atas adalah : "...matriks tersebut didasarkan atas asumsi bahwa studi kasus tunggal dan multi kasus mencerminkan pertimbangan desain yang berbeda dan bahwa di dalam kedua tipe tersebut juga ada kesatuan dan kemudian unit analisis. Karenanya, untuk strategi studi kasus keempat desain tersebut adalah (1) desain kasus tunggal holistik (2) 
desain kasus tunggal terjalin (3) desain multi kasus holistik (4) desain multi kasus terjalin".(dalam, Kriyantono, 2010:46)

Maka tipe desain yang sesuai pada penelitian ini adalah desain penelitian Tipe-2. Karena dalam penelitian ini permasalahan yang dibahas menunjukkan 1 (satu) kasus dengan unit analisis lebih dari satu atau multi analisis. yaitu untuk mengetahui efektifitas komunikasi antarpribadi guru dengan siswa dalam proses belajar mengajar. (Studi Kasus pada Siswa Tunarungu di Sekolah Luar Biasa Sumber Budi Petukangan Selatan, Jakarta Selatan).

Subyek penelitian adalah efektifitas komunikasi antarpribadi guru dengan siswa. Obyek penelitian adalah proses belajar mengajar antara guru dengan siswa tunarungu di Sekolah Luar Biasa Sumber Budi Petukangan Selatan, Jakarta Selatan.

\section{HASIL PENELITIAN DAN PEMBAHASAN}

1. Anak tunarungu memiliki karakter yang berbeda-beda

Anak tunarungu selalu diikuti dengan gangguan berbicara, hal ini disebabkan oleh tidak adanya konsep informasi yang terekam dalam benak anak tunarungu. Ketika tidak ada konsep dalam benak anak tunarungu maka tidak ada rekaman informasi atau kata-kata yang akan dikeluarkan. Maka anak tunarungu selalu mengalami hambatan berbicara, dan anak tunarungu membutuhkan pembelajaran secara khusus dan diiringi dengan latihan demi latihan secara khusus pula. Sulit memahami pembicaraan anak tunarungu, kecuali kita sering berinteraksi dengan anak tunarungu tersebut. Ketika kita sering berinteraksi dengan anak tunarungu, kita dapat memahami karakter anak tersebut sehingga kita mudah memahami bahasa yang mereka ucapkan.

Semua anak tunarungu memiliki karakter yang berbeda-beda sehingga banyak kelucuan dan kenakalan yang mereka lakukan didalam kelas. Karakter anak tunarungu sangat berbeda jika diperhatikan dari segi penampilannya kelihatan kaku dan jika berjalan sedikit agak membungkuk, kemungkinan kurang percaya diri. Gerakan tangannya kelihatan lincah, mungkin hal ini komunikasi yang digunakan sering menggunakan komunikasi non verbal atau komunikasi 
dengan menggunakan anggota badannya. Ketidak mampuannya dalam berbahasa mengakibatkan pernapasannya pendek. Penampilannya kelihatan selalu murung dan adanya perasaan curiga. Terkadang emosinya tidak dapat ia kendalikan sendiri. Hal ini merupakan ciri siswa tunarungu yang mengalami hambatan dalam pendengaran baik permanen ataupun tidak permanen.

Siswa yang mengalami hambatan pendengaran atau yang sering disebut sebagai anak tunarungu, mengalami gangguan pendengaran, gangguan ini dapat dikategorikan dengan ringan, sedang, berat dan tuli total. Siswa tunarungu ini sekalipun diberikan alat bantu pendengaran terkadang mereka tidak merasa nyaman. Alasannya adalah siswa tunarungu merasa berisik ketika mendengarkan suara dari luar. Mungkin mereka terbiasa dengan tidak mendengar atau pendengarannya tidak sempurna. Jadi nyaman dengan kondisinya sendiri.

2. Siswa tunarungu Sekolah Luar Biasa Sumber Budi mayoritas siswa mengalami tuli berat dan hanya beberapa siswa saja yang mengalami ketulian ringan.

Tuli berat atau ringan tidak mempengaruhi seseorang menjadi pintar tetapi kemampuan mereka ditentukan pada IQ yang dimiliki siswa tersebut. Tidak bisa disangkal bahwa tingkat kecerdasan atau IQ mempunyai peran yang besar dalam menentukan keberhasilan seorang siswa. Tapi IQ bukanlah satu-satunya penentu dalam keberhasilan seorang siswa dalam proses belajar, Karena keberhasilan manusia bukan hanya disebabkan oleh faktor kecerdasan saja tetapi ada faktor kecerdasan emosional turut bermain dalam menentukan keberhasilan seorang siswa dalam proses belajar.

Pada dasarnya emosi merupakan dorongan untuk bertindak yang mempengaruhi reaksi seseorang dalam hal ini proses belajar, Sehingga kecerdasan emosional akan mempengaruhi tindakan siswa dalam mengatasi masalah, mengendalikan diri, semangat, dan tekun dalam belajar. Selain itu motivasi bisa berasal dari dalam diri sendiri untuk belajar dengan lebih giat dan rajin.

Motivasi bisa mempengaruhi proses belajar antara siswa dengan gurunya. Proses belajar mengajar antar guru dan siswa tunarungu pasti terdapat hambatan karena siswa sangat miskin dengan bahasa, selain itu apabila siswa tidak 
berkonsentrasi mereka tidak akan memahami apa yang dimaksudkan oleh gurunya karena yang akan menjadi patokan mereka memahami apa yang guru jelaskan melalui komunikasi non verbal seperti mimik, bibir, dan gerakan tubuh.

Memperhatikan kelebihan komunikasi non verbal, Pesan non verbal menyampaikan makna dengan tulus dan kebenarannya tidak diragukan. Sehingga pesannya dapat dipercaya. Komunikasi non verbal menambah dan memperjelas isi pernyataan yang disampaikan. Komunikasi non verbal merupakan cara komunikasi yang lebih efisien dan efektif terutama bagi siswa tunarungu, siswa ini cepat menangkap arti dan maksud yang disampaikan oleh guru pada siswa tunarungu. Komunikasi non verbal memperkaya makna yang disampaikan oleh guru pada siswanya.

3. Komunikasi Antarpribadi Guru dengan Siswa Tunarungu dalam Proses Belajar Mengajar di Sekolah Luar Biasa Sumber Budi. Petukangan Utara

Pendidikan bagi anak-anak tunarungu di Sekolah Luar Biasa merupakan pendidikan yang harus didasarkan pada kemampuan dan kebutuhan siswa yaitu tetap menggunakan kurikulum di sekolah regular pada umumnya tetapi hanya saja materi yang disampaikan harus disesuaikan dengan keterbatasan yang dimiliki anak tunarungu.

Menurut penjelasan dari ibu Wanti, selaku wali kelas lima khusus anak tunarungu di Sekolah Luar Biasa Sumber Budi mengatakan bahwa, Kurikulum yang digunakan anak tunarungu sama dengan kurikulum yang digunakan anak sekolah regular pada umumnya hanya saja tidak semua materi yang ada dibuku paket diberikan ke siswa karena kelemahan yang siswa miliki yaitu miskin bahasa jadi untuk materi yang disampaikan harus yang ringan dan sederhana. Solusi tersebut diterapkan bukan karena siswa tunarungu memiliki IQ yang rendah karena pada umumnya mereka memiliki IQ yang normal hanya saja mereka miskin dalam bahasa jadi terlihat siswa tunarungu memiliki daya tangkap yang kurang.

Di Sekolah Luar Biasa Sumber Budi ini memiliki anak-anak tunarungu berat dan ringan, untuk membedakannya harus didasarkan oleh hasil dari psikolog, karena peraturan sekolah ini tidak sembarangan menerima siswa begitu 
saja tetapi setiap anak yang baru masuk harus memberikan data kesehatan dan asal usul siswa tersebut menderita ketunarunguan, sehingga guru dapat memperlakukan anak itu seperti apa dan mengetahui batas kemampuan mereka.

Dalam hal IQ anak tunarungu tidak banyak berbeda dengan anak normal pada umumnya. Ada yang memiliki IQ tinggi, rata-rata, dan ada pula yang memang IQ rendah. Pada siswa tunarungu perbedaan usia lebih tua tidak menjamin anak tersebut akan lebih pintar dari teman yang memiliki usia lebih muda. Perbedaan usia didalam kelas itu dikarenakan setiap anak memasuki sekolah tidak sesuai dengan usia pada umunya melainkan ada beberapa siswa yang masuk sekolah dasar di Sekolah Luar Biasa Sumber Budi yang sudah berusia 13 tahun. Pada Sekolah Luar Biasa Sumber Budi untuk klasifikasi kelas disesuaikan dengan batas kemampuan anak tersebut dan hasil tes pendengaran jadi di SD Sumber Budi ada siswa kelas 1 SD yang berusia 11 tahun dan untuk siswa kelas lima memiliki usia berkisar 15-18 tahun.

Kurikulum yang digunakan Sekolah Luar Biasa Sumber Budi sama dengan sekolah dasar regular pada umumnya hanya saja dalam penyampaian materi tidak semua materi diberikan ke siswa tunarungu melainkan dipilih yang bobotnya lebih ringan dan sederhana dengan tujuan siswa tunarungu dapat memahami materi yang sudah disampaikan oleh guru mereka. Jika diamati, siswa tunarungu lebih menyukai mata pelajaran matematika dibandingkan pelajaran bahasa Indonesia atau ilmu pengetahuan sosial dikarenakan ilmu pengetahuan sosial lebih banyak menggunakan bahasa-bahasa asing yang mereka belum pernah dengar sebelumnya jadi mereka sulit untuk memahami materi tersebut, sedangkan pelajaran berhitung seperti matematika tidak banyak menggunakan bahasa dalam menjelaskannya jadi siswa lebih mudah memahaminya.

Selain itu pada pelajaran matematika, siswa lebih terlihat tenang dan benarbenar memperhatikan guru yang sedang menjelaskan selain itu pada saat pelajaran matematika apabila gurunya mengalami kesalahan dalam berhitung mereka bisa membantah gurunya jadi terlihat mereka lebih aktif dan banyak memberikan pertanyaan kepada guru mereka jadi terlihat mereka lebih mengerti pelajaran matematika jika dibandingkan pelajaran-pelajaran yang banyak menggunakan 
bahasa. Pada Sekolah Luar Biasa Sumber Budi setiap siswa tidak diwajibkan memiliki buku paket dan lembar kerja siswa (LKS) karena siswa tidak akan bisa memahami kalimat-kalimat yang ada dibuku paket atau di lembar kerja tersebut karena terlihat anak tunarungu merupakan anak yang miskin bahasa jadi setiap materi yang ingin disampaikan melalui buku paket atau lembar kerja siswa setiap guru harus merangkumnya terlebih dahulu agar materi tersebut lebih sederhana, tidak hanya seperti itu saja tetapi siswa tidak diwajibkan memiliki buku pelajaran dikarenakan faktor ekonomi keluarga.

Pada Sekolah Luar Biasa Sumber Budi rata-rata siswa termasuk dalam ekonomi menengah ke bawah walaupun sekolah mendapat bantuan dari pemerintah untuk buku paket dan alat bantu dengar tetapi jumlah yang diberikan pemerintah tidak sesuai dengan jumlah siswa yang ada di Sekolah Luar Biasa Sumber Budi. Jadi buku tersebut diperuntukan untuk guru saja dan untuk alat bantu dengar diberikan kepada siswa yang mengalami ketulian ringan saja.

Berdasarkan observasi yang peneliti lakukan di dalam kelas, saat ibu Wanti sedang menerangkan materi dan mereka terlihat serius mengamati apa yang sedang dijelaskan oleh ibu Wanti tetapi ada juga diantara mereka yang tidak memperhatikan karena sedang asik bermain handphone.

Pada saat guru menerangkan pun mereka tidak hanya bermain handphone tetapi ada juga yang suka berbuat kejahilan pada teman wanita dikelas sebelah yaitu kelas empat seperti menarik baju hangat, lalu di sembunyikan dan terkadang mereka suka jahil dengan mencolek-colek teman wanita mereka dikelas empat. Di sekolah luar biasa Sumber Budi dalam satu ruangan dibagi menjadi tiga kelas yang hanya dibatasi dengan papan sebagai sekatnya, sekat tersebut yang tertutup hanya atas saja sedangkan bawahnya tidak tertutup Jadi keusilan mereka dilakukan dibawah pembatas yang tidak tertutup. Kenakalan seperti itu membuat mereka menjadi kurang kosentrasi dalam belajar, tetapi guru ibu Wanti sudah memahami kebiasaan-kebiasaan yang mereka lakukan jadi setelah penyampaian materi selesai dijelaskan, ibu Wanti langsung memberikan pertanyaan dan menunjuk mereka untuk mengerjakan soal tersebut di depan kelas sebagai 
hukuman apabila siswa tidak mengamati apa yang sedang diterangkan guru mereka.

komunikasi yang biasa dilakukan pada proses belajar mengajar didalam kelas adalah komunikasi antarpribadi karena sangat tepat digunakan untuk komunikasi didalam kelas antara guru dengan siswa tunarungu. Pada penyampaian materi, guru lebih banyak menggunakan bahasa oral dibandingkan bahasa isyarat karena sekolah mengharuskan siswa tunarungu terbiasa menggunakan komunikasi oral. oleh karena itu komunikasi tersebut harus dilakukan secara langsung dan face to face, yang menjadi patokan siswa untuk memahami materi tersebut adalah mimik bibir dan gerakan tubuh guru jadi pada saat guru menyampaikan materi siswa harus benar-benar memperhatikan apa yang guru katakan.

Cara yang dilakukan untuk meningkatkan komunikasi oral siswa tunarungu di Sekolah Luar Biasa Sumber Budi yaitu dengan menerapkan kebiasaan membaca bersama-sama didalam kelas dengan mengeluarkan suara. Selain itu ada satu cara yang dilakukan guru untuk melatih komunikasi oral siswa tunarungu yaitu dengan merangsang mereka untuk mengingat sesuatu yang sudah dilakukan atau menceritakan apa yang mereka lihat ketika mereka dalam perjalanan ke sekolah dan melatih saraf mulut mereka untuk berbicara yaitu melalui percakapan dari hati ke hati, percakapan tersebut sekaligus cara untuk melakukan pendekatan kepada siswa agar guru dapat memahami apa yang sedang dirasakan siswa, percakapan tersebut dilakukan pada saat belajar dikelas sebelum mereka memulai materi setiap harinya.

Pendekatan tersebut agar siswa bisa belajar untuk terbuka dan menceritakan masalah yang mereka hadapi karena seperti yang diketahui bahwa salah satu karakter dari seorang tunarungu yaitu sangat tertutup.

Komunikasi antarpribadi guru dengan siswa tunarungu tidak hanya terjadi pada saat belajar mengajar didalam kelas tetapi pada saat siswa tunarungu kelas lima sedang melakukan pembuatan jahe bubuk di aula sekolah mereka. Praktek tersebut dipimpin oleh ibu Wanti yaitu wali kelas untuk siswa tunarungu kelas lima. Pada proses pembuatan jahe bubuk, guru mengarahkan siswa-siswanya 
dengan menggunakan komunikasi antarpribadi yang dilakukan secara oral, komunikasi antarpribadi terjadi pada saat guru memberikan perintah kepada siswanya untuk menggantikan apa yang dilakukan oleh gurunya.

Peneliti melihat dalam praktek tersebut kurangnya komunikasi antara siswa dan guru dalam memberikan pengarahan karena terlihat guru lebih dominan dalam praktek pembuatan jahe tersebut dibanding siswa jadi apapun yang ingin dilakukan siswa hanya mengikuti yang gurunya lakukan karena langkah-langkah awal pembuatan jahe dilakukan oleh gurunya selanjutnya baru diteruskan oleh siswa. Menurut saran dan instruksi dari guru mereka, peneliti mencoba untuk mendekati dan berkenalan dengan mereka satu persatu, terlihat mereka cukup menerima peneliti untuk bergabung di aula tersebut mengamati mereka yang sedang praktek.

Pada saat praktek tersebut peneliti terus mendekati siswa-siswa untuk mencoba berinteraksi dan berkomunikasi dengan mereka tetapi mereka melihat peneliti seperti orang asing jadi mereka tidak mau dekat dengan peneliti. Pada saat itu, peneliti berusaha untuk terus mendekati mereka dan mencoba untuk berkomunikasi dengan mereka tetapi sulit sekali karena mereka selalu menjauh apabila peneliti dekati tetap saja siswa tunarungu tersebut menjauhi peneliti, tetapi walaupun seperti itu siswa meninggalkan peneliti dengan memberikan senyuman. Diantara siswa tersebut, hanya ada satu siswa yang bernama Banu yang bisa diajak untuk berkomunikasi dan tidak menjauhi peneliti sehingga pada saat itu peneliti hanya bisa berkomunikasi dengan Banu saja. Pada komunikasi yang dilakukan peneliti dengan Banu terlihat Banu cukup bisa merespon peneliti tetapi dalam pertanyaan yang sangat sederhana karena apabila diberikan pertanyaan yang kalimatnya cukup panjang Banu tidak akan mengerti dan antara jawaban dengan pertanyaan tidak sesuai.

4. Efektivitas Komunikasi Antarpribadi Guru dengan Siswa Tunarungu dalam Proses Belajar Mengajar di Sekolah Luar Biasa Sumber Budi

Komunikasi antarpribadi guru dengan siswa tunarungu yang digunakan pada proses belajar mengajar di Sekolah Luar Biasa Sumber Budi adalah lebih mengedepankan efektivitas untuk mencapai keberhasilan dalam belajar dan 
mencapai suatu visi dan misi sekolah demi kesuksesan bersama. Hasil dari proses belajar mengajar ada dua kemungkinan yaitu berhasil dan tidak berhasil, keberhasilan atau tidak suatu proses belajar dapat dilihat dari kesesuaian metode yang diterapkan dan cara penyampaian materi yang digunakan oleh guru kepada siswa tunarungu.

Metode yang digunakan di Sekolah Luar Biasa Sumber Budi yaitu metode demonstrasi, tanya jawab, ceramah, penugasan, dan metode drill atau metode pengulangan kata. Dari beberapa metode yang diterapkan sekolah, hanya beberapa metode yang sering digunakan untuk belajar mengajar di dalam kelas yaitu metode tanya jawab, penugasan, dan metode pengulangan kata. Metode belajar merupakan salah satu cara untuk mencapai suatu keberhasilan dalam proses belajar. Pada Sekolah Luar Biasa Sumber Budi, metode yang digunakan sebagian besar sudah sama dengan metode belajar di sekolah dasar regular pada umumnya, hanya saja berbeda dalam penyampaian. Metode drill atau pengulangan kata digunakan pada pelajaran tertentu seperti bahasa Indonesia atau ilmu sosial lainnya. Dalam penyampaiannya, guru menggunakan komunikasi antarpribadi dengan siswa tunarungu agar hasilnya lebih maksimal. Dengan komunikasi antarpribadi, guru bisa melihat gerakan bibir mereka ketika diperintah untuk mengucap kata-kata, metode drill berguna untuk melatih siswa tunarungu untuk melatih rongga mulutnya agar terbiasa menggunakan bahasa oral, sedangkan metode penugasan dan tanya jawab hampir diterapkan pada setiap mata pelajaran tiap harinya. Pada Sekolah Luar Biasa Sumber Budi, metode demonstrasi dan ceramah hanya digunakan di acara-acara tertentu saja; jadi, untuk kedua metode ini penerapannya kurang dimaksimalkan.

Pada siswa tunarungu efektivitasnya suatu komunikasi bisa ditentukan dari bagaimana guru menyampaikan informasi tersebut kepada siswanya. Seperti yang diketahui bahwa anak tunarungu merupakan anak yang miskin dengan bahasa atau sangat sedikit mengusai kosakata sehingga mereka memiliki kekurangan dalam menerima informasi dan menyampaikan informasi kepada orang lain. Begitu sebaliknya, guru juga memiliki kendala dalam menyampaikan materi kepada siswa tunarungu. 
Menurut ibu wanti kendala yang mereka hadapi dalam menyampaikan materi kepada siswa tunarungu yaitu siswa sulit menerima materi dikarenakan mereka miskin akan bahasa jadi guru berkesulitan dalam menyampaikannya, selain itu juga ada kebiasaan siswa yang suka bercanda pada saat guru menerangkan sehingga menyebabkan siswa kurang berkonsetrasi padahal yang menjadi patokan siswa tunarungu untuk memahami apa yang telah disampaikan guru adalah mimik bibir dan gerakan tubuh, jadi apabila mereka tidak memperhatikan mereka tidak akan mengerti.

Efektivitas suatu komunikasi bisa terhambat apabila ada kendala-kendala dalam proses penyampaiannya, pada proses belajar mengajar didalam kelas konsentrasi merupakan hal yang sangat dibutuhkan oleh siswa tunarungu karena siswa hanya bisa membaca mimik bibir dan gerak tubuh guru. Keterbatasan anak tunarungu menjadikan kendala yang dialami guru pada saat menyampaikan materi kepada siswa, salah satu cara yang dilakukan oleh sekolah luar biasa Sumber Budi dalam mengatasi masalah tersebut yaitu dengan membuat rangkuman materi sebelum materi tersebut akan disampaikan kepada siswa tunarungu.

Merangkum merupakan cara yang tepat digunakan Sekolah Luar Biasa Sumber Budi untuk mencapai efektivitas suatu komunikasi pada proses belajar siswa tunarungu, dengan merangkum materi sebelum diberikan ke siswa maka siswa akan lebih memahami materi tersebut karena kalimatnya sudah disederhanakan dan telah disesuaikan dengan kemampuan siswa tunarungu.

Menurut ibu Wanti bahwa metode dan proses penyampaian materi yang sudah berlangsung belum mencapai efektivitas secara maksimal karena terdapatnya kendala tersebut. Metode pembelajaran yang kurang pas dapat membuat tidak tercapainya sebuah efektivitas belajar serta dapat membuat penyampaian materi terlihat tidak maksimal. Peneliti mengamati Sekolah Luar Biasa Sumber Budi kurang disiplin dalam penggunaan alat bantu dengar, sehingga dalam penyampaiannya guru akan merasa kesulitan untuk menjelaskan dan guru akan mengeluarkan suara yang keras pada saat belajar mengajar.

Peneliti mendapat informasi kalau siswa Sekolah Luar Biasa Sumber Budi mayoritas ekonomi menengah kebawah oleh karena tidak semua siswa bisa 
membeli alat bantu dengar tetapi pemerintah suka memberikan bantuan untuk alat bantu dengar tersebut tetapi belum dimaksimalkan penggunaanya.

Menurut peneliti untuk mengetahui efektivitas atau tidak komunikasi antarpribadi guru dan siswa tunarungu pada proses belajar mengajar dapat dilihat dari hasil wawancara dengan siswa tunarungu kelas 5 Sekolah Dasar Luar Biasa Sumber Budi.

Seperti yang dikatakan oleh Banu (informan 1) pada wawancara pada tgl 05 September 2016. Apabila peneliti mengamati Banu merupakan salah satu siswa tunarungu Sekolah Luar Biasa Sumber Budi yang aktif dan lebih bisa bersosialisasi dengan orang lain selain siswa tunarungu, dalam perbincangan dengan peneliti Banu tidak didampingi dengan gurunya jadi Banu termasuk siswa yang memiliki kosakata yang banyak dibandingkan dengan teman-teman lainnya. Pertanyaan yang diberikan peneliti kepada Banu cukup banyak karena peneliti ingin melihat kemampuan Banu dalam komunikasi. Peneliti melihat bahwa Banu termasuk siswa tunarungu dalam kategori IQ sedang, karena peneliti melihat beberapa hasil nilai ulangan Banu yang cukup lumayan bagus dan ada beberapa nilai ulangan tersebut dibawah 5 yaitu dimata pelajaran ilmu pengetahuan alam dan ilmu pengetahuan sosial.

Hasil wawancara dengan Bella (informan 2) yang dilakukan pada tanggal 05 September 2016. Jika dikategorikan Bella termasuk dalam siswa tunarungu yang memiliki IQ yang tinggi karena nilai-nilai Bella semuanya diatas 7, untuk pelajaran Bella termasuk anak cerdas dan aktif walaupun Bella termasuk siswa yang mengalami tuli total, walaupun Bella anak yang cerdas tetapi Bella tidak bisa berinteraksi dengan peneliti karena terlihat Bella selalu berusaha untuk menjauhi peneliti jadi pada saat peneliti mewawancarai Bella ditemani oleh ibu Wanti. Pada wawancara Bella dengan peneliti terlihat Bella memang anak tunarungu yang miskin dengan bahasa jadi pada saat wawancara Bella harus dibantu dengan ibu Wanti untuk bisa mengerti apa yang dikatakan peneliti. Apabila diperhatikan mereka bukan tidak paham apa yang peneliti katakan tetapi mereka hanya malu dan menjauhkan diri apabila peneliti mendekatinya dan mengajak mereka berbicara, karena seperti yang peneliti perhatikan ketika siswa tunarungu 
berbicara dengan gurunya komunikasi yang mereka gunakan berupa isyarat yang umum bukan isyarat khusus dan apa yang dikatakan gurunya sama seperti yang peneliti katakan.

Wawancara yang dilakukan dengan Nurul (informan 3) pada tanggal 13 September 2016 bahwa Nurul termasuk siswa tunarungu yang pendiam dan pemalu, setiap peneliti menatap wajahnya nurul selalu menundukkan kepala dan tersenyum saja. Pada wawancara dengan Nurul saat itu ibu Wanti juga mendampingi Nurul karena menurut keterangan dari ibu Wanti Nurul termasuk kategori siswa tunarungu yang memiliki IQ yang rendah dan sangat miskin bahasa jadi apapun yang peneliti katakan Nurul tidak paham dan hanya terdiam, dalam wawancara tersebut ibu Wanti sangat membantu peneliti dalam berkomunikasi dengan peneliti jadi peniliti tidak berkesulitan dalam mewawancarainya. Jika peneliti mengamati dari hasil nilai ulangannya terlihat nilai Nurul kurang bagus, masih banyak nilai-nilai Nurul yang dibawah 6 dan terlihat Nurul tidak mempunyai mata pelajaran yang digemari karena semua nilainya amat sangat rendah sekali dibanding dengan teman sekelasnya.

Wawancara dengan Ilham (informan 4) tanggal 16 September 2016 dan peneliti memperhatikan kalau Ilham merupakan anak yang cukup pendiam yang bisa dilihat dari tingkah lakunya pada saat bermain dengan teman-temannya, Jika peneliti amati nilai-nilai yang didapatkan Ilham cukup bagus tetapi hanya saja ada beberapa mata pelajaran yang nilainya kurang bagus seperti, ilmu pengetahuan sosial dan ilmu pengetahuan alam. Dalam kategori pendengaran Ilham merupakan siswa yang mengalami ketulian total tetapi memiliki IQ yang normal sehingga dalam hal pelajaran Ilham termasuk anak cukup pintar.

Wawancara dengan Derby (informan 5) tanggal 16 Agustus 2016. Hampir semua siswa tunarungu di Sekolah Luar Biasa Sumber Budi yang mengalami tuli total tetapi Derby masuk dalam kategori tuli ringan, Tingkah laku Derby seperti anak normal lainnya karena dia suka bergaul dengan teman-teman tunarungu diluar sekolahnya. Derby termasuk anak tunarungu yang pandai berteman dan teman Derby banyak didaerah mana saja. Dalam hal pelajaran Nilai-nilai ulangan Derby cukup bagus dan hanya bahasa Inggris dan ilmu pengetahuan alam saja 
yang mendapat nilai dibawah enam untuk mata pelajaran lain nilainya diatas tujuh semua berarti Derby termasuk kedalam IQ normal hanya saja dimata pelajaran tertentu tidak bisa mengusai karena keterbatasan yang dimilikinya.

Dari hasil keseluruhan wawancara yang peneliti lakukan pada siswa kelas 5 Sekolah Dasar Luar Biasa Sumber Budi bahwa komunikasi antarpribadi guru dan siswa tunarungu di Sekolah Luar Biasa Sumber Budi tercapai suatu efektivitas berkomunikasi. Terlihat dari lima siswa dari hasil ulangan siswa yang peneliti lihat pada saat observasi dan hasil tanya jawab pelajaran dengan mereka. Hasil nilai pelajaran mereka dipengaruhi oleh IQ bukan karena kemampuan mendengarnya, walaupun dari kelima siswa tersebut ada beberapa siswa yang mengalami ketulian total tapi tidak terlalu mempengaruhi nilai-nilai sekolah mereka. Jika peneliti amati keseluruhan dari siswa tunarungu khususnya dikelas lima lebih menyukai pelajaran matematika dan pelajaran yang kurang mereka sukai yaitu Bahasa Inggris, Bahasa Indonesia, Ilmu Pengetahuan Sosial dan Ilmu Pengetahuan Alam.

5. Bagaimanakah efektivitas komunikasi antarpribadi yang dilakukan oleh guru dan siswa tunarungu di Sekolah Luar Biasa Sumber Budi Petukangan Selatan, Jakarta Selatan

Kondisi anak-anak tunarungu sangat membutuhkan perhatian dan kasih sayang dari orang sekitar, karena tunarungu merupakan sebuah kondisi dimana anak mengalami ketunarunguan atau permasalahan dalam fungsi pendengarannya sehingga anak tersebut mempunyai kekurangan berupa 'kemiskinan' dalam bahasa. 'Kemiskinan' bahasa yang dimiliki anak tunarungu mengakibatkan proses komunikasi mereka menjadi terhambat dan sulit untuk menerima informasi yang disampaikan.

Banyak orang tua yang tidak mengakui keberadaan anak karena kekurangan yang dimiliki anak tersebut. Jadi menurut mereka, anak yang mengalami ketunarunguan tidak memerlukan sekolah formal dan pendidikan yang layak, padahal anak tunarungu sangat perlu dibimbing dan diberikan pengarahan agar bisa membentuk tingkah laku, kepribadian dan menambah kosakata yang banyak serta mendapatkan ilmu pengetahuan yang tidak bisa mereka dapatkan 
dirumah. Sekolah luar biasa Sumber Budi merupakan sekolah khusus yang diperuntukan untuk anak tunarungu dan tunagrahita, di Sekolah Luar Biasa Sumber Budi dan mereka akan didik dan dilatih kemampuan berbicara mereka dengan latihan-latihan yang dikhususkan untuk melatih saraf pendengaran mereka dan melatih saraf mulut mereka agar terbiasa mengeluarkan kata, selain itu sekolah melatih mereka untuk menggunakan bahasa oral pada setiap komunikasi yang mereka lakukan dan pengunaan bahasa isyarat hanya sebagai komunikasi untuk mendukung saja.

Maka dalam komunikasi antarpribadi yang terjadi antara guru dan siswa tunarungu dapat membantu siswa tunarungu dalam memahami materi pelajaran yang disampaikan oleh guru pada proses belajar mengajar. Mengacu pada teori komunikasi antarpribadi dan teori penyusupan sosial, dapat terlihat pada keseharian di sekolah antara guru dengan siswa tunarungu yang memiliki kedekatan yang sangat dalam yang dilakukan dengan melakukan percakapan dari hati ke hati tentang apa yang dialami siswa karena seperti yang diketahui bahwa siswa tunarungu memiliki sifat yang sangat tertutup dan pandai menyembunyikan rahasia. Jadi kedekatan guru sangat diperlukan untuk memahami karakter siswa tunarungu agar sifat tertutup tersebut tidak berdampak negatif terhadap perilaku siswa tersebut. Percakapan dari hati kehati merupakan cara guru untuk melakukan pendekatan dengan mereka dan biasanya percakapan tersebut dilakukan pada saat sebelum memulai pelajaran yang fungsinya agar guru akan lebih mengerti dan memahami apa yang sedang dirasakan siswanya, dengan adanya metode percakapan dari kehati maka dapat membantu tercapainya suatu efektivitas komunikasi antarpribadi karena diantara mereka sudah terjadi kedekatan. Seperti ciri-ciri karakteristik efektivitas melalui sudut pandang keterbukaan, empati dan sikap mendukung. Keterbukaan yang dimaksud yaitu guru harus bisa mengajak siswa untuk bisa terbuka dengan apa yang bisa dirasakan siswanya dari situlah akan ada sikap empati guru dengan apa yang dirasakan siswa dan akan menimbulkan rasa terus mendukung siswa untuk terus maju dan menjadi lebih baik. 
Keefektifan komunikasi antarpribadi dapat terjadi apabila penerima dapat menginterprestasikan pesan yang diterimanya sebagaimana dimaksud oleh pengirim dan keefektifan dapat terlihat dari seberapa jauh sebab dan akibat yang ditimbulkan dari komunikasi tersebut. Berlangsungnya efektifitas komunikasi antarpribadi merupakan keberhasilan bagi manusia dalam berkomunikasi yang dapat membuka serta menjalin komunikasi atau hubungan dengan sesamanya. Komunikasi antarpribadi yang dilakukan di Sekolah Luar Biasa Sumber Budi ini selain untuk bisa mendekatkan antara guru dengan siswa selain itu juga untuk memaksimalkan cara penyampaian materi pelajaran pada siswa tunarungu agar dapat tersampaikan dengan baik karena seperti yang diketahui bahwa siswa tunarungu adalah siswa yang miskin akan bahasa jadi mereka harus mendapatkan perhatian khusus dalam berkomunikasi agar tercapai efektivitas komunikasi dan tercapai juga tujuan dari proses belajar mengajar disekolah.

Peneliti menggunakan teori penyusupan sosial Irwin Altman dan Dalmas Taylor yang menyatakan bahwa teori penyusupan sosial merupakan salah satu teori yang menjelaskan bagaimana mengumpamakan struktur kepribadian seseorang dengan struktur bawang merah yang berlapis-lapis. Teori ini memiliki 3 lapisan pada struktur kepribadian seseorang diantaranya, yaitu untuk mengetahui lapisan terluar dari kepribadian seseorang tentang bagian dari diri seseorang yang hanya Nampak dari luar, namun apabila dapat menembus lapisan terluar seseorang akan dapat mengetahui bagian yang merupakan semi-private dari orang tersebut sampai ketingkah laku yang hanya diketahui orang-orang tertentu, dan apabila kemudian dapat menembus ke lapisan hingga bagian yang paling terdalam maka seseorang akan dapat mengetahui pribadi dan unik seseorang seperti karakter, sifat, dan konsep dirinya ataupun masalah-masalah yang dihadapi seseorang. Apabila dilihat dari ketiga lapisan kepribadian tersebut, terjadi pada hubungan kedekatan antara guru dengan siswa tunarungu dimana guru dapat mengenali siswanya sampai ke lapisan yang paling dalam yaitu psikologis siswa.

Kaitannya teori penyusupan sosial dengan komunikasi antarpribadi, yakni karena teori ini dianggap teori yang paling cocok dengan judul yang peneliti teliti dan teori ini juga mempunyai maksud dan tujuan untuk mengungkap kepribadian 
seorang siswa dengan sejelas-jelasnya sampai lapisan kepribadian yang terdalam dari siswa tersebut. Jadi pendekatan ini berfungsi sebagai proses pengenalan kepribadian yang dilakukan guru dengan siswa tunarungu agar guru dapat lebih memahami kemampuan siswa dalam belajar, karena dengan guru memahami keadaan jiwa siswanya maka guru akan mencari cara seperti apa memperlakukan siswanya pada saat belajar disekolah. Apabila di antara guru dengan siswa sudah terjadi pengenalan dan pendekatan maka akan mudah dan cepat untuk siswa memahami apa yang disampaikan oleh gurunya. Karena pesan yang disampaikan oleh gurunya bisa diterima dengan baik oleh siswa, dari tersampaikannya pesan dan terjadi hubungan timbal balik berarti komunikasi antarpribadi guru dan siswa tunarungu dapat efektif. Teori penyusupan sosial yang dilakukan Sekolah Luar Biasa Sumber Budi yaitu bagaimana cara guru melakukan pengenalan dari lapisan luar sampai kelapisan paling terdalam dari siswanya. Dalam hal ini lapisan terluar yang diketahui guru pada siswanya yaitu guru mengetahui karakter siswa yang bisa dilihat dari luar bahwa siswa rapi dalam berpakaian seragam berarti dapat dilihat bahwa siswa tersebut merupakan anak yang merawat diri dan bersih. Apabila guru dapat menembus lapisan luar tersebut, guru akan mengetahui perilaku siswa yang tidak bisa diketahui orang lain seperti, pada siswa kelas 5 Sekolah Dasar Luar Biasa Sumber Budi pernah terjadi kehilangan uang tetapi dengan adanya kedekatan guru dengan siswa-siswanya, akhirnya guru mengetahui siapa yang mencuri uang tersebut, Walaupun anak tersebut berada pada ekonomi menengah keatas tetapi karena kurang mendapat perhatian orang tuanya maka dari itu siswa tersebut berperilaku seperti itu, siswa tersebut suka mencuri uang orang tuanya dirumah dan prilaku ini juga dilakukan di luar rumah. Memasuki lapisan terdalam dari siswa yaitu guru sangat memahami sifat yang dimiliki siswanya seperti guru mengetahui sifat Bella yang selalu berbicara besar yang tidak sesuai dengan faktanya tidak hanya hal seperti itu tetapi guru juga mengetahui keadaan ekonomi yang dialami oleh siswa tersebut berdasarkan informasi yang didapatkan guru dari siswanya. 


\section{KESIMPULAN}

Komunikasi antarpribadi antara guru dengan siswa tunarungu di Sekolah Luar Biasa Sumber Budi berjalan efektif karena dengan adanya percakapan dari hati kehati maka terbentuklah keterbukaan siswa untuk menceritakan kepada gurunya tentang apa yang dialami dan yang sedang dipikirkan anak tersebut. Keterbukaan siswa akan membuat guru empati dan merasakan apa yang dirasakan oleh siswa dengan terus memberikan perhatian, kasih sayang serta dukungan yang luar biasa dari orang tua siswa, tidak hanya itu saja tetapi dengan adanya keterbukaan guru akan memahami bagaimana akan memperlakukan siswanya dalam hal belajar karena siswa tunarungu kemampuan komunikasinya sangat rendah. Solusinya adalah dengan menggunakan komunikasi non verbal. Bentuk komunikasi non verbal sangat mendukung dalam kegiatan proses belajar mengajar. Hal ini untuk mendukung kegiatan belajar mengajar. Seiring dengan meningkatnya kemampuan berkomunikasi, anak tunarungu mulai mencoba untuk mengutarakan maksud dan keinginannya kepada gurunya dengan komunikasi non verbal. Sehingga komunikasi nonverbal untuk anak tunarungu sangatlah penting agar ia dapat berkomuikasi atau berinteraksi dengan gurunya.

Guru melakukan pengenalan dengan siswa dari lapisan luar sampai kelapisan yang paling terdalam dari siswa tersebut. Tujuan dari pengenalan tersebut untuk mengungkap kepribadian siswa dengan sejelas-jelasnya sampai lapisan kepribadian yang terdalam dari siswa tersebut. Jadi pendekatan ini berfungsi sebagai proses pengenalan kepribadian yang dilakukan guru dengan siswa tunarungu agar guru dapat lebih memahami kemampuan siswa dalam belajar, karena dengan guru memahami keadaan jiwa siswanya maka guru akan mencari cara seperti apa memperlakukan siswanya pada saat belajar disekolah. Apabila di antara guru dengan siswa sudah terjadi pengenalan dan pendekatan maka akan mudah dan cepat untuk siswa memahami apa yang disampaikan oleh gurunya. Maka dilakukanlah metode bagaimana untuk mengenali siswa tunarungu agar guru dapat mengenali siswanya dengan baik. Seperti mengikuti bagaimana siswa dapat menguasai bahasa yang disampaikan oleh guru. Memahami bagaimana minat dan kebutuhan komunikasi siswa. Bagaimana cara guru mengucapkan kata- 
kata agar siswa dapat memahami kata yang disampaikan oleh gurunya. Menyampaikan kata yang wajar atau kata yang mudah untuk dipahami oelh siswa. Hal ini disampaikan baik secara ekspresif maupun dengan cara reflektif. Menuntun siswa tunarungu secara bertahap mengenali kata sesuai dengan kemampuan mereka agar terjadi efektifitas komunikasi antara siswa tunarungu dengan guru.

\section{DAFTAR PUSTAKA}

Ardianto, Elvinaro. 2010. Metogologi Penelitian untuk Public Relations Kuantitatif dan Kualitatif. Bandung : Simbiosa Rekatama Media

Budyatna, Muhammad, 2015, Teori-teori Mengenai Komunikasi Antarpribadi, Jakarta : Prenadamedia Group

Cangara, Hafied. 2004. Pengantar Ilmu Komunikasi, Cetakan V, PT. Raja Grafindo Persada, Jakarta

Devito. 1997. Komunikasi Antar Budaya, Erlangga, Jakarta

Effendy. 2004. Onong, Uchjana, Ilmu Komunikasi dan Praktek, PT. Remaja Rosdakarya. Bandung

Faisal, Sanapiah. 2008. Format-Format Penelitian Sosial, PT. Raja Grafindo. Jakarta

Hergenhahn dan Olson, 2009, Theories of Learning (Teori Belajar), Jakarta : Prenadamedia Group.

Herdiansyah, Haris. 2012. Metodologi Penelitian Kualitatif : Jakarta, Salemba Humanika

K.Yin, Robert. 2008. Studi Kasus: Desain dan Metode, terjemah M. Djauzi Mudzakir.Jakarta: PT Raja Grafindo Persada.

Kriyantono, Rachmat. 2006. Teknik Praktis Riset Komunikasi. Jakarta : Kencana.

Littlejohn dan Foss, 2009. Teori Komunikasi, Theories of Human Communication, Salemba Humanika, Jakarta.

Moleong, Lexy J. 2010. Metodologi Penelitian Kualitatif. Edisi Revisi. Bandung : PT. Remaja Rosdakarya.

Rianto, Yatim, 1996, Metodologi Pelitian Pendidikan, Suatu Tinjauan Dasar, Sic. Surabaya. 